\title{
GENETICALLY DIVERSE BASALT GEOCHEMICAL SIGNATURES DEVELOPED IN THE RIO DAS VELHAS GREENSTONE BELT, QUADRILATERO FERRIFERO, MINAS GERAIS, BRAZIL
}

\author{
MARCIA ZUCCHETTI ${ }^{1}$, LYDIA MARIA LOBATO ${ }^{2}$ AND FRANCISCUS JACOBUS BAARS ${ }^{3}$
}

\begin{abstract}
On the basis of major and trace element analysis, the metabasalts of the Nova Lima Group, Rio das Velhas Greenstone Belt, are divided into tholeiites and magnesian tholeiites. Using rare-earth element patterns, the rocks are subdivided into five geochemical populations $(\mathrm{I}-\mathrm{V})$. The chemical variations demonstrated on binary variations diagrams, using major and trace elements, proves this division. Population $\mathrm{I}$ is comprised of magnesian basalts and represents the most primitive terms of the sample population, with high $\mathrm{MgO}$, Ni and Cr. Populations II, III, IV and V are differentiated terms evolved from compositions like those of Population I, with low compatible-element contents. The geochemical behavior, represented principally by the trace elements, shows that Population I may have formed by the partial fusion of a mantleplume source (P-MORB). The other populations are differentiated by fractional crystallization from a melt of composition similar to that of Population I. Populations IV and V present geochemical patterns reflecting mixing processes that have been caused by fractional crystallization together with contamination. The Nova Lima Group metabasalts are derived from an ocean-floor environment, as evidenced by structure (pillow lavas) and lithological associations (banded iron formation and metachert). The geochemical characteristics indicate that at least some of the metabasalts were formed by a mantle plume. These characteristics permit the identification of a submarine plateau environment. That some mafic-rock populations show evidence for contamination and the occurrence of felsic volcanic rocks suggest the presence of an island-arc or back-arc type environment.
\end{abstract}

INTRODUCTION The Rio das Velhas Greenstone Belt (RVGB) is an Archean volcanic-sedimentary sequence that has undergone a complicated history of folding, faulting, granitoid intrusion, and greenschist facies metamorphism. The geology of the belt has been described in several works (Dorr 1969, Ladeira 1980, Oliveira et al. 1983, Vieira \& Oliveira 1988, Vieira 1991, Zucchetti et al. 1998a), but the mapping of Baltazar \& Silva (1996) and the genetically related lithofacies associations proposed by Pedreira \& Silva (1996) and Baltazar \& Pedreira (1998) form the basis of the discussion presented here (Fig. 1). The greenstone belt is formed by basic-ultrabasic volcanic rocks at the base, associated with intermediate felsic volcanic rocks, followed by clastic sedimentary rocks at the top. The basic volcanism is represented by massive and pillowed basaltic flows that belong to the Nova Lima Group, constituting the mafic-ultramafic and chemical-pelitic volcanosedimentary lithofaciological associations. The metabasalts are associated with banded iron formation and metachert, indicating extrusion in a submarine environment.

GEOCHEMISTRY Whole-rock major- and trace-element analyses were performed on 23 samples of metabasalts (Fig. 2). There is much controversy about element mobility (e.g. Humpris 1984, Michard 1989 and Bau 1991), especially for rocks that have been multiply deformed and metamorphosed. For Archean volcanic rocks, Morris (1993, in Morris \& Witt 1997) shows that the coherency of nigh-field-strength elements (HFSE) and rare-earth elements (REE) provides strong evidence for immobility in mafic and ultramafic volcanic rocks. Although the basalts of the RVGB underwent metamorphism in the greenschist facies and hydrothermal alteration, the samples under study display no or minimal petrographic and chemical effects of alteration. The samples have no veins or secondary minerals. The sum $\left(\mathrm{H}_{2} \mathrm{O}+\right.$ $\mathrm{CO}_{2}$ ) is most commonly $<3.0 \mathrm{wt}$. $\%$, or is at least $<4.0 \mathrm{wt}$. $\%$.

RARE-EARTH ELEMENT GEOCHEMISTRY The rare earth element patterns separate the metabasalts into five populations (Zucchetti 1998, Zucchetti et al. 1998b). The Gd anomaly is attributed to an analytical error and eliminated by linear interpolation with the elements Sm and $\mathrm{Tb}$. The new Gd norm values are shown on the diagrams as $\mathrm{Gd}_{\mathrm{R}}(\mathrm{Gd}$ recalculated)

Relative to chondrite values, Population I presents parallel HREE patterns and slight LREE enrichment, whose fan-splay array indicated that the rock population evolved through some type of magmatic differentiation in relation to a mantle source (Fig. 3). In comparison with N-MORB, HREE are depleted and La is slightly enriched. In relation to P-MORB, the HREE patterns are parallel and depleted, while the LREE have $(\mathrm{La} / \mathrm{Sm})_{\mathrm{n}}=0.87$. The parallelism between the basalt patterns indicates a similarity between the formative processes of Population I and that of plume-type basalts. The difference in the concentration of the elements below the norm $\left(\mathrm{La}_{\mathrm{N}}=0.87 \mathrm{e} \mathrm{Yb}_{\mathrm{N}}=\right.$ 0.42 ) can be explained by the fact that Archean basalts have compositions depleted in incompatible elements compared to those of present-day basalts (Condie 1985, 1989). Population II (Fig. 4a-c) maintains the same REE patterns of Population I, although it is more enriched and differentiated. In relation to P-MORB (Fig. 4c), the group's patterns is entirely parallel and has values close to 1 , indicating a similarity between both, not only regarding the formative processes but also magmatic composition. Populations III (Fig. 5) and IV (Fig. 6 follow the same REE patterns, pointing to progressive magmatic differentiation. Samples representative of population V (Fig. 7) have parallel REE patterns, however exhibiting varying concentrations of the remaining elements (Fig. 2). Sample MZ24 (MgO > 9\%) is similar to those of Population I due to the parallelism of the HREE and its impoverished composition in relation to P-MORB, despite its unique, steep LREE enrichment. In figure 8, samples of Populations II and V are normalized with respect to the arithmetic average of those of Population I, also shown in the diagram (Gd anomaly not to be considered). The REE are parallel and enriched from the magnesian to the tholeiitic absalts, confirming the differentiation among the populations. Basalts display respectively positive and negative Eu anomalies in samples of Population I and of the less differentiated types. Population I would represent incipient fractionation with concentration of plagioclase crystals. With progressive magmatic differentiation, the most evolved populations acquire the negative $\mathrm{Eu}$ anomaly since this element was retained by early-formed plagioclase.

\section{MAJOR AND TRACE ELEMENT COMPOSITIONS The}

samples define three groups in the diagram by Jensen (1976): high-Fe tholeiites, high-Mg tholeiites and basaltic komatiites (Fig. 9a). Since the latter do not conform to the definition of basaltic komatiites by Arndt \& Nisbet (1982), they are considered as magnesian basalts according to Sylvester et al. (1997) who define them in the Archean as having $\mathrm{MgO}>9 \%$ (Fig. 9b).

The $\mathrm{Al}_{2} \mathrm{O} 3 \mathrm{TiO}_{2}$ e Ni contents are plotted against \#Mg in figure lOa-c, thus characterizing Populations I-IV. Population I displays a trend in which the $\mathrm{Al}_{2} \mathrm{O}_{3}$ content increases in relation to lower $\# \mathrm{Mg}$, while the remaining samples display smaller variations in $\mathrm{ALO}_{3}$ tenors. Population I has approximately constant $\mathrm{TiO}_{2}$ values, while Populations II, III and IV display a progressive increase in $\mathrm{TiO}_{2}$ with \#Mg diminution. Population I has high Ni contents, while Populations II and III present continuous differentiation and Population IV displays a mixing line. These diagrams display an evolutionary trend that parts from Population I and passes to Populations II, III and IV, suggesting an evolution by fractional crystallization, as described by the REE

1 - CPRM - Geological Survey of Brazil, Av. Brasil 1731, Funciondrios, 30140-002, Belo Horizonte, MG, cprmnels@estaminas.com.br

2 - Institute de Geociências, CPMTC, Universidade de Minas Gerais, Cx. Postal 719, Av. AntSnio Carlos 6627, Pampulha, 31270-901, Belo Horizonte, MG, lobato@igc.ufmg.br

3 - Roots Rock Ltda., Av. Afonso Pena 4343/402, Mangabeiras, 30130-008, Belo Horizonte, MG/ Department of Geological Geosciences, University of Cape Town, baarsf@skynet.com.br 


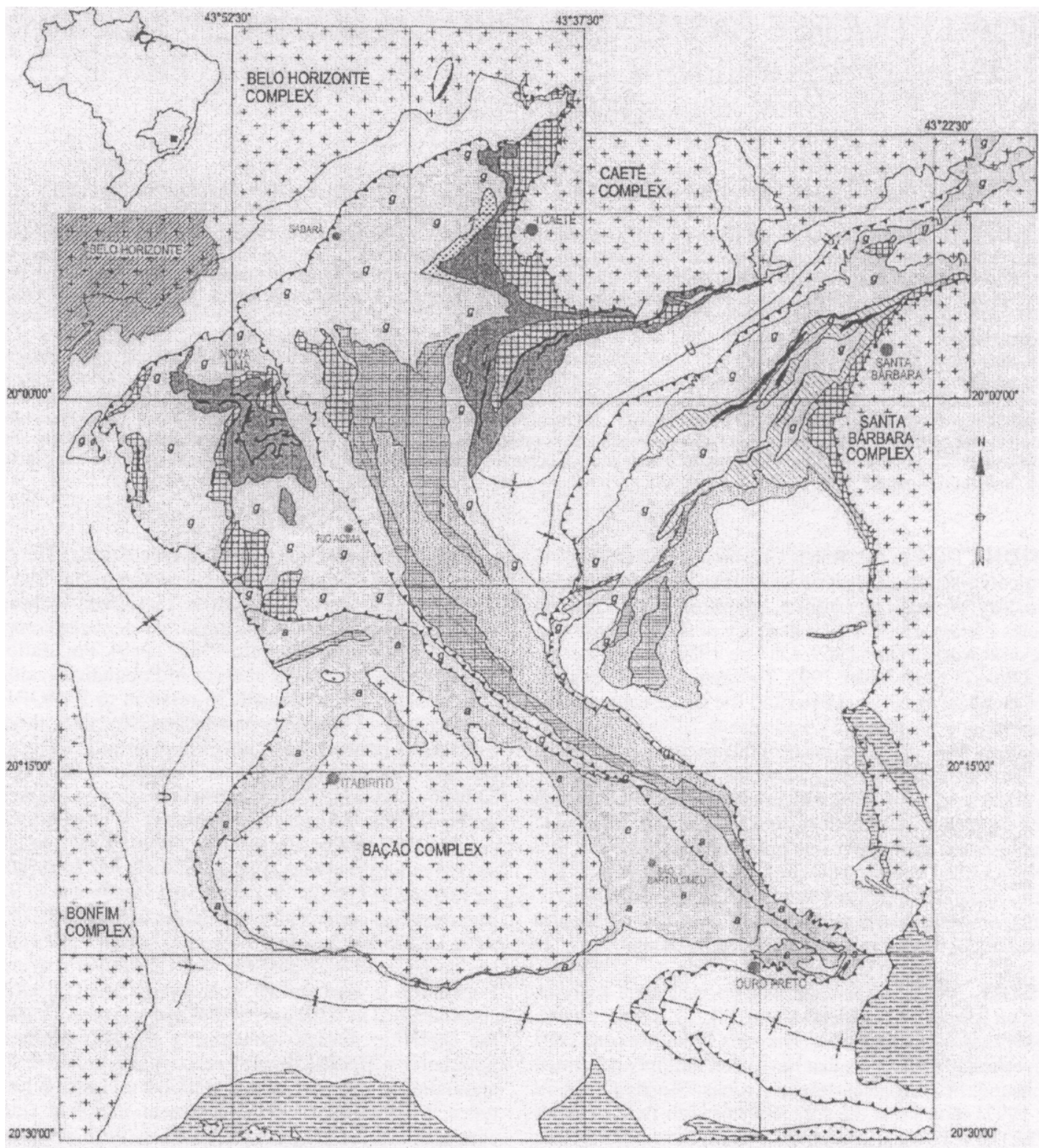

LEGEND

PROTEROZOIC COVERS

RIO DAS VELHAS SUPERGROUP

MAQUINE GROUP

[2] Casa Fate Formation (Non-Marine Association)

[int Palmital Formation (Coastal Assodiation)

NOVALIMA GROUP

[9] Resedimented Association - Amphibolite Facies $(a)$

6 Volcanidastic Association

[2] Clasticchemical Volcanic, Clastic and

ner. Volcano-chemical ( $\Gamma$ Iron Formation

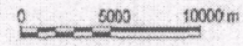

203050

[IIIt) Voicanic, Maficultramafic Assoclation

Eב UNDIVIDED RIO DAS VELHAS SUPERGROUP

$\because$ GRANITE GNEISS COMPLEXES 
Figure 2 - Whole-rock analyses of metabasalts of Nova Lima Group (RVGB). Major elements (wt. \%) determined at the Geological Survey of Brazil - LAMIN. Trace elements (ppm) analysed at ACTLABS, Ontario, Canada. LOI: loss on ignition.

\begin{tabular}{|c|c|c|c|c|c|c|c|c|c|c|c|c|c|c|c|c|c|c|c|c|c|c|c|}
\hline & \multicolumn{6}{|c|}{ Population 1} & \multicolumn{9}{|c|}{ Population D } & \multicolumn{3}{|c|}{ Population IJ } & \multicolumn{3}{|c|}{ Populdion IV } & \multicolumn{2}{|c|}{ Popilation $\bar{v}$} \\
\hline & MZ29B & MZ29C & $\mathrm{MZ31}$ & MZ32 & MZ33A & MZ4I & MZ2OA & MZ22A & MZ23A & $\mathrm{MZ30A}$ & TNI & $\overline{T N 3}$ & TN7A & LM00 & MZ18A & MZ36A & MZ399 & FR19 & $M Z \bar{T} \bar{A}$ & MZZ3SB & $\overline{M Z 37}$ & $\mathrm{MZ2A}$ & $\overline{M Z A 2 A}$ \\
\hline $\mathrm{SiO}_{2}$ & 52,90 & 53,20 & 51,80 & 52,40 & 50,90 & 51,40 & 47,00 & 52,30 & 50,50 & 54,10 & 52,60 & 53,00 & 52,00 & 51,70 & 46,70 & 51,50 & 52,60 & 46,90 & 55,00 & 57,90 & 55,10 & 52,90 & 56,60 \\
\hline $\mathrm{TiO}_{2}$ & 0,47 & 0.52 & 0.52 & 0.52 & 0,63 & 0,41 & 1,30 & 0.63 & 0,73 & $0, \mathbf{8 3}$ & 0,63 & 0,83 & 0,73 & 0,70 & 2.10 & 1,50 & 1,50 & 2,10 & 1,40 & 1,70 & 1.30 & $0,4 t$ & 0,94 \\
\hline $\mathrm{Al}_{2} \mathrm{O}_{3}$ & 11.30 & 12.30 & 10,40 & 9,40 & 11,30 & 12,80 & 15.10 & 14,20 & 14,20 & 13,20 & 14,20 & 14.20 & 14,20 & 14.10 & 13.20 & 13,20 & 14,20 & 12.80 & 14,60 & 14,20 & 14,20 & 10,40 & 13,20 \\
\hline $\mathrm{F}=\mathrm{O}$ & 2,80 & 3.10 & 3.20 & 2.40 & 2,70 & 3,20 & 5,50 & 4,20 & 4,20 & 3,60 & 3,80 & 3,10 & 4,40 & 2,68 & 4.10 & 6,00 & 4,40 & 5.80 & 2,30 & 3,70 & $4,50 \mathrm{k}$ & 3,694 & 5,10 \\
\hline FeO & 7,50 & 7,00 & 7,30 & 7.10 & 7,40 & 7,10 & 8,20 & 6,50 & 6,40 & 7,10 & 7,30 & 8,20 & 4,90 & 5,94 & 11,30 & 7,10 & 7,60 & 10,60 & 6,50 & 6,50 & 6,50 & 7.20 & 6,20 \\
\hline MnO & 0,17 & 0.18 & 0,18 & 0,13 & 0.14 & 0,13 & 0,15 & 0,12 & 0,13 & 0,18 & 0,13 & 0,14 & 0.15 & 0,13 & 0,21 & 0.13 & 0.14 & 0,17 & 0.12 & 0,12 & 0.12 & 0,15 & 0,12 \\
\hline $\mathrm{MgO}$ & 11,90 & 10,50 & 13,50 & 14,10 & 13,10 & 11,90 & 7,40 & 7,50 & 7,70 & 6,20 & 7,00 & 6,00 & 5,30 & 6,53 & 6.60 & 6,40 & 6,20 & 6,20 & 4,80 & 4,50 & 5,90 & 12,50 & 4,60 \\
\hline $\mathrm{CaO}$ & 8,40 & 8,20 & 7,30 & 8,20 & 6,50 & 5,30 & 10,10 & $\mathbf{9 , 0 0}$ & 12,80 & 8,60 & 8,60 & 8,10 & 15,30 & 10,40 & 11,50 & 7,20 & 6,00 & 10,00 & 7,90 & 4,00 & 6.80 & 7,00 & 7.10 \\
\hline $\mathrm{Na}_{2} \mathrm{O}$ & 0,68 & 1,60 & 0,81 & $0,4 I$ & 1,20 & $3+20$ & 1,50 & 2,30 & I, 40 & 2,30 & 1,80 & 3,00 & 0,68 & 3,85 & 1,60 & 3,80 & 4,70 & 2,30 & 4,90 & 2,50 & 2,60 & 1,50 & 1,80 \\
\hline $\mathrm{K}_{2} \mathrm{O}$ & 0,12 & $<0,05$ & 0,07 & 0,85 & 1,10 & 0,48 & 0,48 & 0,05 & $<0,05$ & 0,36 & 0,36 & 0.11 & $<0,05$ & 0,06 & 0,06 & 0,48 & 0,05 & 0,05 & 0,19 & 1,80 & 0,36 & 0,48 & 0,91 \\
\hline $\mathrm{P}_{3} \mathrm{O}_{5}$ & 0,17 & 0,30 & 0,29 & 0,22 & 0,27 & 0,21 & 0,25 & 0,19 & 0,23 & 0,31 & 0,26 & 0,27 & 0,17 & 0,14 & 0,36 & 0,31 & 0,30 & 0,51 & 0,35 & 0,35 & 0,30 & 0,24 & 0,32 \\
\hline $\mathrm{H}_{2} \mathrm{O}$ & 3,19 & 2,84 & 3,87 & 3,43 & 3,85 & 3,39 & 2,39 & 2,19 & 1,99 & 2,01 & 2,14 & 2,39 & 0,97 & 1,80 & 2,62 & 1,99 & 2.09 & 2.79 & 1,05 & 2,14 & 2,49 & 3,36 & 2.39 \\
\hline $\mathrm{CO}_{2}$ & 0,08 & 0,09 & 0,10 & 0,09 & 0,08 & 0,11 & 0,12 & 0,16 & 0,09 & 0,45 & 0,20 & 0,40 & 0,88 & 2,60 & 0,07 & 0,07 & 0,08 & 0,15 & 0,17 & 0,31 & 0,10 & 0,07 & 0,65 \\
\hline Total & 99,68 & 99,87 & 99,34 & 99,25 & 99.17 & 99,63 & 99,49 & 99,34 & 100,41 & 99,24 & 99,02 & 99,74 & 99,72 & 100,63 & 100,42 & 99,68 & 99,86 & 100,37 & 99,28 & 99,72 & 100.27 & 99,81 & 99,91 \\
\hline LOI & 3,10 & 2,90 & 4,00 & 4,00 & 3,90 & 3,20 & 2,60 & 2,30 & 2,00 & 2,50 & 2,80 & 2,40 & 1,80 & - & 2,50 & 2,20 & 2.10 & 2,60 & 1,30 & 2,80 & 2,00 & 3,40 & $3,(\boldsymbol{x})$ \\
\hline $\mathrm{Cr}$ & 992,00 & 670,00 & 988,00 & 893,00 & 962,00 & 715,00 & 261,00 & 171,00 & 113,00 & 163,00 & 165,00 & 47,00 & 67.00 & 30,00 & 82,00 & 117,00 & 146,00 & 128,00 & 120,00 & 19,00 & 136,00 & 915,00 & $-10,00$ \\
\hline $\mathrm{Ni}$ & 212,00 & 164,00 & 193,00 & 184,00 & 210,00 & 174,00 & 105,00 & 125,00 & 75,00 & 62,00 & 87,00 & 53,00 & 66,00 & $\$ 2,00$ & 40,00 & 80,00 & 70,00 & 53,00 & 34,00 & -10,00 & 4,00 & 276,00 & 37,06 \\
\hline $\mathrm{C}_{0}$ & 57,00 & 49,00 & 56,00 & 53,00 & 54,00 & 53,00 & 50,00 & 47,00 & 45,00 & 45,00 & 45,00 & 46,00 & 44,00 & 47,00 & 52,00 & 46,00 & 48,00 & 49,00 & 37,00 & 34,00 & 42,00 & 60,00 & 35,00 \\
\hline $\mathrm{Ta}$ & 0,14 & 0,19 & 0,13 & 0,11 & 0,13 & 0,16 & 0,45 & 0,22 & 0,19 & 0,25 & 0.21 & 0,21 & 0,18 & 0,24 & 0,64 & 0,41 & 0,38 & 0,52 & 0,54 & 0,54 & 0,56 & 0,27 & 0,47 \\
\hline Nb- & 1,40 & 1,50 & 1,30 & 1,20 & 1,40 & 1,50 & 4,90 & 2,60 & 2,70 & 3,20 & 2,40 & 2,80 & 2,40 & 2,70 & 9,90 & 5,70 & 5,30 & 7.70 & 7,000 & 7,60 & 7,00 & 2,60 & 5,70 \\
\hline Hf & 0.80 & 0.90 & 0,80 & 0.80 & 0.90 & 0,90 & 2,00 & 1,30 & 1,40 & 1,60 & 1,40 & 1.80 & 1,50 & 1,60 & 4,30 & 3,30 & 2,90 & 3,50 & 3,60 & 3,90 & 3,50 & 1,40 & 3,00 \\
\hline $\boldsymbol{Z r}$ & 29,00 & 32,00 & $26 ; 00$ & $\mathbf{3 0 , 0 0}$ & 29,00 & 31,00 & 70,00 & 46,00 & 49,00 & 56,00 & 50,00 & 60,00 & 55,00 & 53,00 & 150,00 & 111,00 & 109,00 & 123,00 & 130,00 & 137,00 & 125,00 & 50,00 & 107,00 \\
\hline $\mathbf{Y}$ & 12,00 & 13,00 & 12,00 & 11,00 & 12,00 & 12,00 & 25,00 & 17,00 & 18,00 & 19,00 & 23,00 & 19,00 & 16,00 & 16,00 & 51,00 & 33,00 & 32,00 & 44,00 & 36,00 & 44,00 & 41,00 & 14,00 & 25,00 \\
\hline Th & 0,45 & 0,46 & 0,40 & 0,36 & 0,42 & 0,46 & 2.13 & 0,80 & 0,85 & 1.19 & 1,02 & 1,22 & 1,02 & 1,15 & 2,41 & 2,17 & 2,03 & 1,81 & 3,83 & 5,73 & 3,78 & 2,21 & 4,97 \\
\hline La & 3,17 & 2,67 & 3,44 & 2,16 & 2,53 & 1,91 & 9,24 & 3,98 & 4,65 & 5.99 & 7,88 & 6,81 & 6,36 & 6,29 & 15,70 & 12,40 & 11,40 & 13.20 & 17,90 & 27,10 & 18,60 & 8,75 & 21,40 \\
\hline $\mathrm{Ce}$ & 6,69 & 5.92 & 6,89 & 4,98 & 5,71 & 5,09 & 18,80 & 9,32 & 10,40 & 12,80 & 11.50 & 13,80 & 12,40 & 12,70 & 33,90 & 26,20 & 23,10 & 29,20 & 35,90 & 46,90 & 36,00 & 16,50 & 36,80 \\
\hline Pr & 0,86 & 0,82 & 0.89 & 0,67 & 0,84 & 0,75 & 2,42 & 1,28 & 1,38 & 1,67 & 2,06 & 1,88 & 1,62 & 1,60 & 4,65 & 3,37 & 3,08 & & & 6,38 & 4,44 & 2.00 & 4,52 \\
\hline Nd & 4,24 & 4,18 & 4,44 & 3,40 & 4,26 & 3,97 & 11,50 & 6,32 & 6,66 & 8,00 & 9,99 & 8,85 & 7,47 & 7,38 & 22,80 & 15.70 & 14,50 & 19,50 & 19,70 & 28,30 & 19,60 & 8,49 & 18,90 \\
\hline Sm & 1,24 & f. 34 & 1.24 & 1,09 & 1.36 & 1,26 & 3,20 & I,86 & 1,97 & 2,32 & 2,94 & 2,52 & 2,05 & 1,94 & 6,66 & 4,38 & 4.12 & & & 7,09 & 4,96 & 2.06 & 4.17 \\
\hline Eu & 0.53 & 0,60 & 0,67 & 0,44 & 0,62 & 0.44 & 1.04 & 0,64 & 0,66 & 0.78 & 0,90 & 0,81 & 0.79 & 0,65 & 1,85 & 1,4 & 1,2 & 1,64 & $t, 3$ & 1,9 & 1,12 & 0,63 & 1,20 \\
\hline Gd & 1,30 & 1,34 & 1,29 & 1,09 & 1,3 & 1,2 & 3. & 1,92 & 2,02 & 2,41 & & 2,52 & 2,04 & 2,04 & 6,4 & 4,3 & 4,10 & 5,4 & & & 5,08 & 2,03 & 3.95 \\
\hline $\mathbf{T b}$ & 0,27 & 0,31 & 0.28 & 0,25 & 0,30 & 0,29 & 0,64 & $(0,4\}$ & 0,42 & 0,48 & (6),62 & 0,51 & 0,41 & 0,38 & 1,31 & 0,8 & 0,83 & 1,09 & 0,95 & 1,24 & 0,97 & 0,37 & 0.66 \\
\hline Dy & 1,88 & 2,07 & 1,88 & 1,79 & 2,04 & 2,02 & 4,16 & 2,76 & 2,93 & 3,23 & 4,05 & 3,40 & 2,67 & 2,54 & 8.39 & 5.7 & 5,25 & 7.23 & 5,97 & 7. & 6.40 & 2,32 & 4,01 \\
\hline Ho & 0,39 & 0,43 & 0,39 & 0,36 & 0,42 & 0,42 & 0,83 & 0,56 & 0,61 & 0,65 & 0,80 & 0,67 & 0,54 & 0,52 & 1,70 & 1,1 & 1.05 & 1,46 & 1,20 & 1. & 1.31 & 0,46 & 0,79 \\
\hline Er & 1,16 & 1,29 & 1,16 & 1,05 & 1,24 & 1,20 & 2,44 & 1,65 & 1,76 & 1,91 & 2,24 & 1,99 & 1.57 & 1.56 & 5.02 & 3.31 & $.3,07$ & 4,33 & 3.62 & 4,25 & 3,89 & 1.39 & 2.37 \\
\hline $\mathbf{T m}$ & 0.18 & 0,20 & 0,18 & 0,16 & 0,19 & 0,19 & 0,37 & 0,26 & 0,28 & 0,30 & 0,32 & 0,30 & 0,24 & 0,24 & 0,75 & 0,51 & 0,45 & 0,66 & 0.55 & 0,61 & 0,61 & 0,21 & 0,34 \\
\hline$Y \mathbf{b}$ & 1,15 & 1,35 & 1,20 & 1,07 & 1,30 & 1,24 & 2,47 & 1,71 & 1,81 & 1.97 & 1,94 & 1,92 & 1,58 & 1,62 & 4,89 & 3,26 & 2,44 & 4,36 & 3,56 & 3,66 & 3,85 & 1,36 & 2,21 \\
\hline L & 0,18 & 0,21 & 0,19 & 0,18 & 0,20 & 0,20 & 0,37 & 0,26 & 0,29 & 0,31 & 0,31 & 0,30 & 0,24 & 0,26 & 0,77 & 0,50 & 0,45 & 0,66 & 0,54 & 0,56 & 0,60 & 0,22 & 0,35 \\
\hline
\end{tabular}
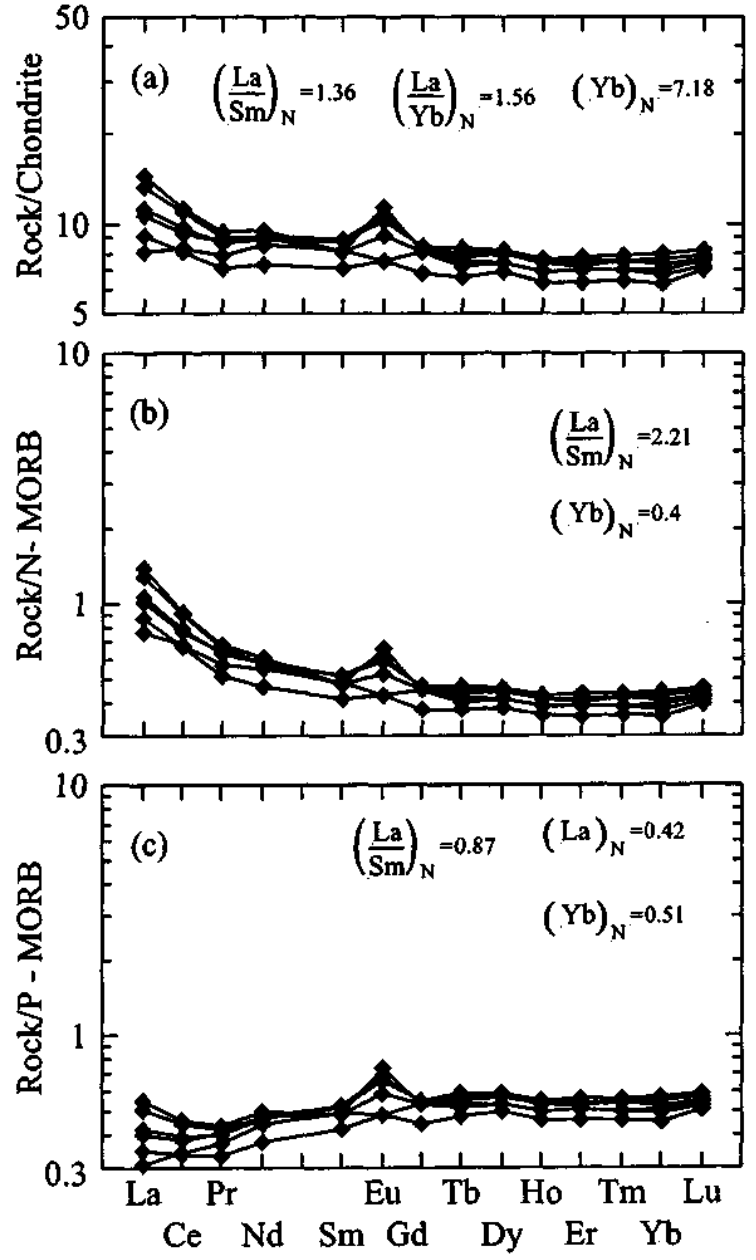

Figure 3 - REE diagrams of Population I normalized to (a) chondrite; (b) NMORB; (c) P-MORB. Norms after Sun \& McDonough (1989).
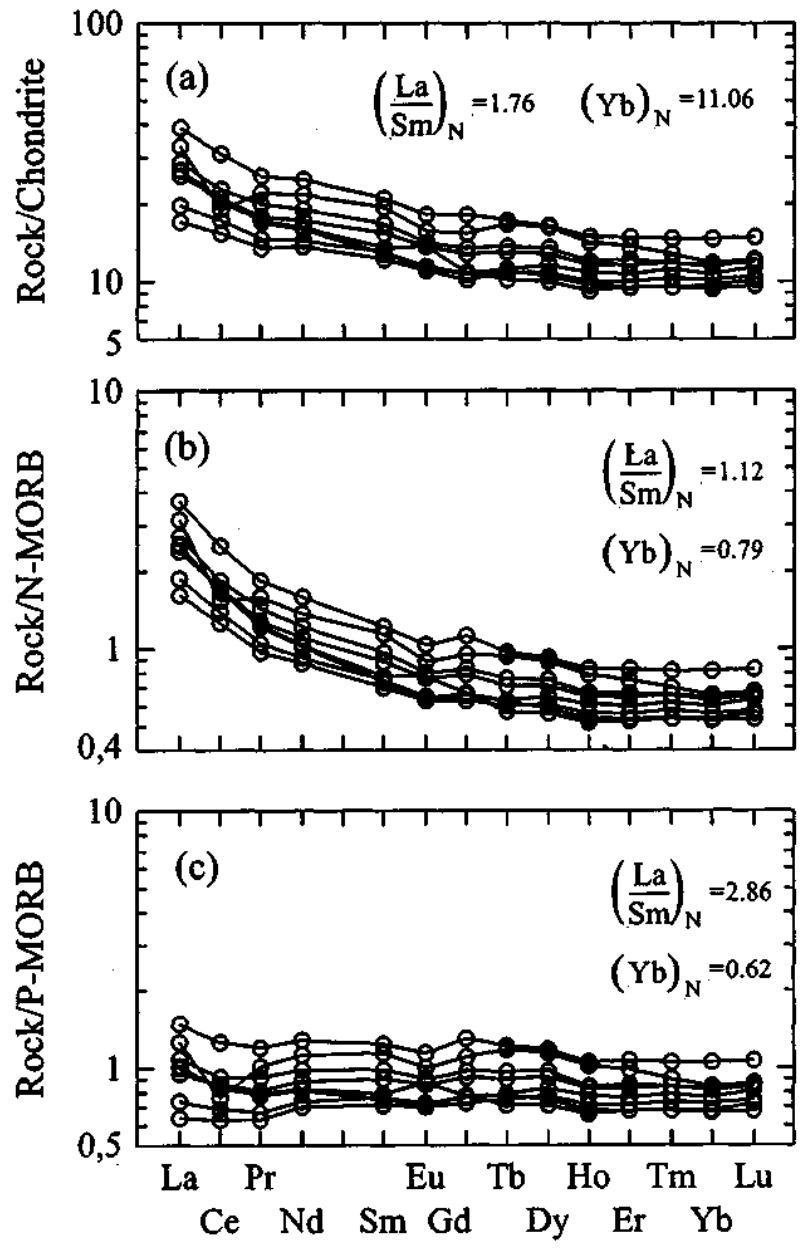

Figure 4 - REE diagrams of Population II normalized to (a) chondrite; (b) $\mathrm{N}$ MORB; (c) P-MORB. Norms after Sun \& McDonough (1989). 


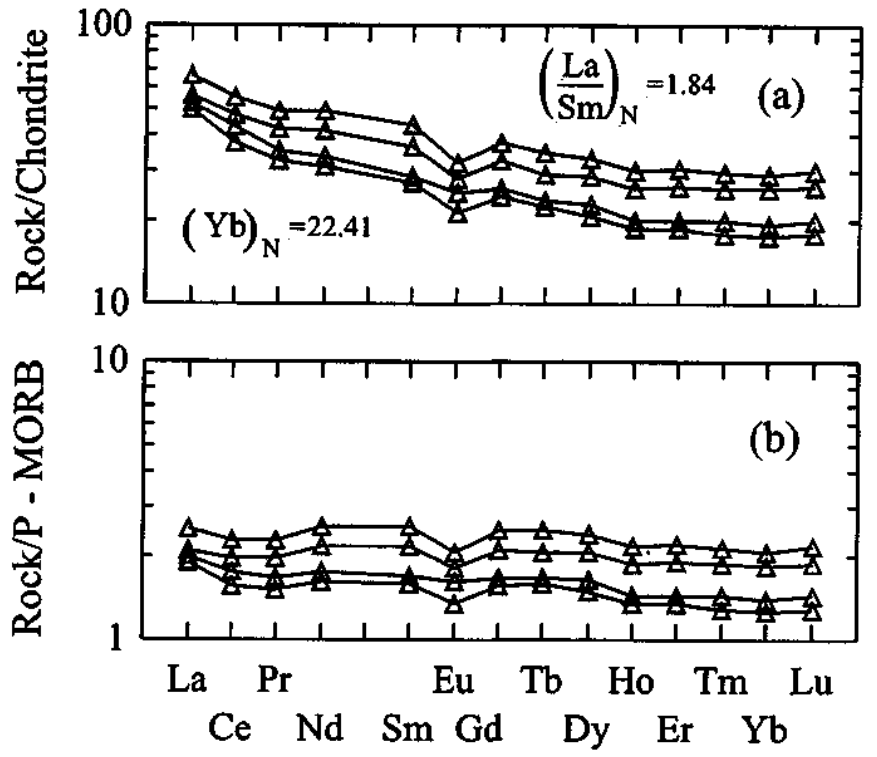

Figure 5 - REE diagrams of Population III normalized to (a) chondrite; (b) $P$. MORB. Norms after Sun \& McDotough (l989).
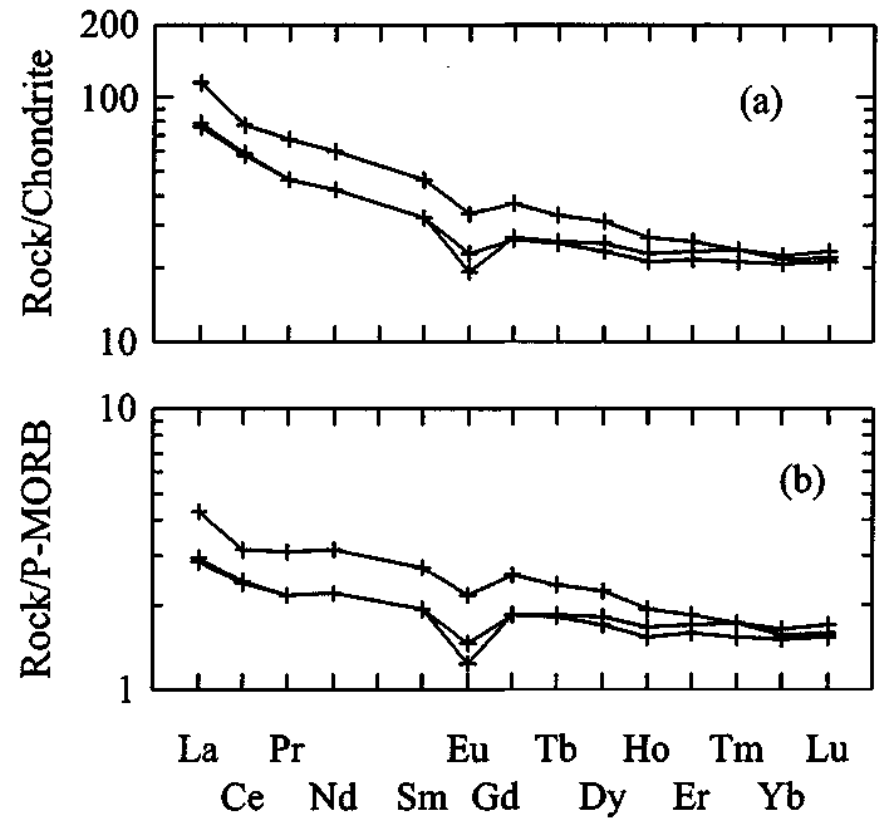

Figure 6 - REE diagrams of Population IV normalized to (a) chondrite; (b) PMORB. Norms after Sun \& McDonough (1989).

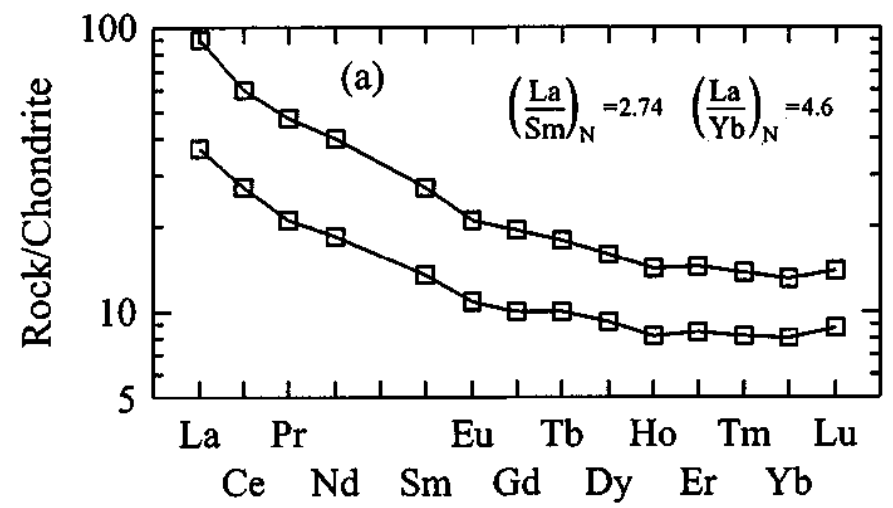

patterns. With regard to incompatible elements (e.g. Y, Th, Ta, Hf and $\mathrm{Nb}$ ), each population displays the same trends presented above. The variation of $\mathrm{MgO}$ versus $\mathrm{Zr}$ (Figure 11) neatly separates the populations and displays a magmatic trend, evolving from Population I towards the others. Population I represents a magma saturated in $\mathrm{Mg}$ with constant Zr. Population II is transitional between a liquid saturated in Mg and another saturated in Zr. Populations III and IV, and a single sample of $\mathrm{V}$ present constant $\mathrm{Mg}$ and saturated $\mathrm{Zr}$, probably related to zircon crystallization. Population IV displays a $\mathrm{Mg}$ depletion trend in conjunction with an enrichment in $\mathrm{Zr}$, resembling a mixing line. The magmatic evolution observed by way of the binary diagrams indicates magmatic differentiation of the magnesian terms for Populations II, III and IV, and that the latter occurred by way of fractional crystallization. Population $\mathrm{V}$ presents peculiar characteristics, in that the samples have parallel REE trends with a heterogeneous geochemical behavior with regard to the other elements. The ratio diagram for $\mathrm{Th} / \mathrm{Ta}$ versus $\mathrm{La} / \mathrm{Yb}$ (Fig. 12) shows that the rocks constitute the trend with the largest ratios of the incompatible elements. This diagram also emphasizes the mixing trend of Population IV, displayed in other variation diagrams.

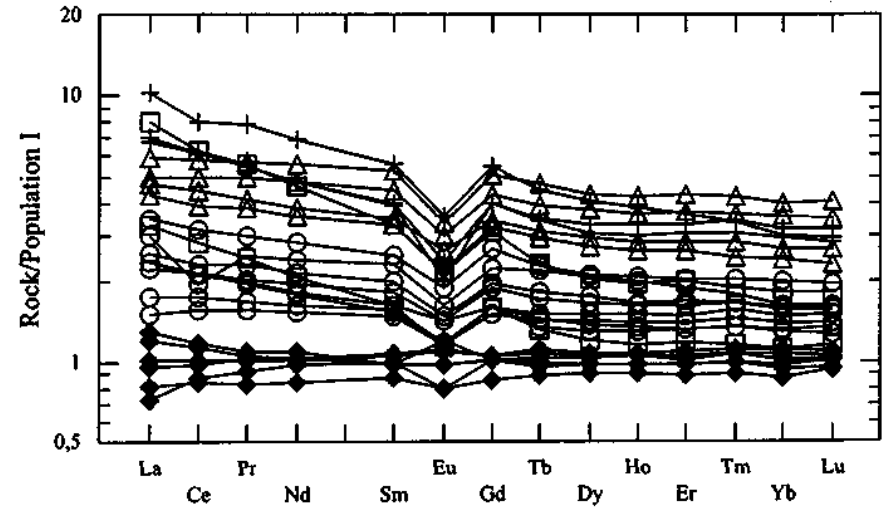

Figure 8 - REE diagrams of Populations II, III, IV and V normalized to the average of Population I. Symbols: Population I - rhomb; Population II circle ; Population III - triangle; Population IV - cross; Population V xanare.

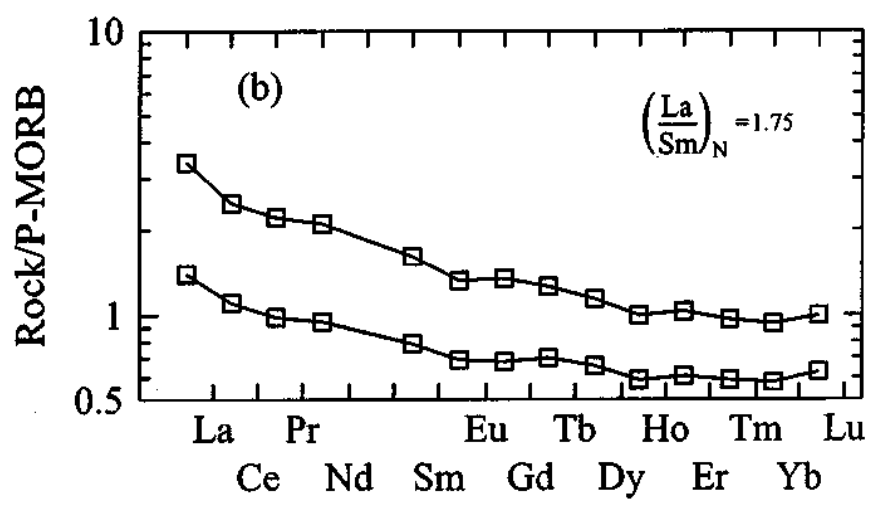



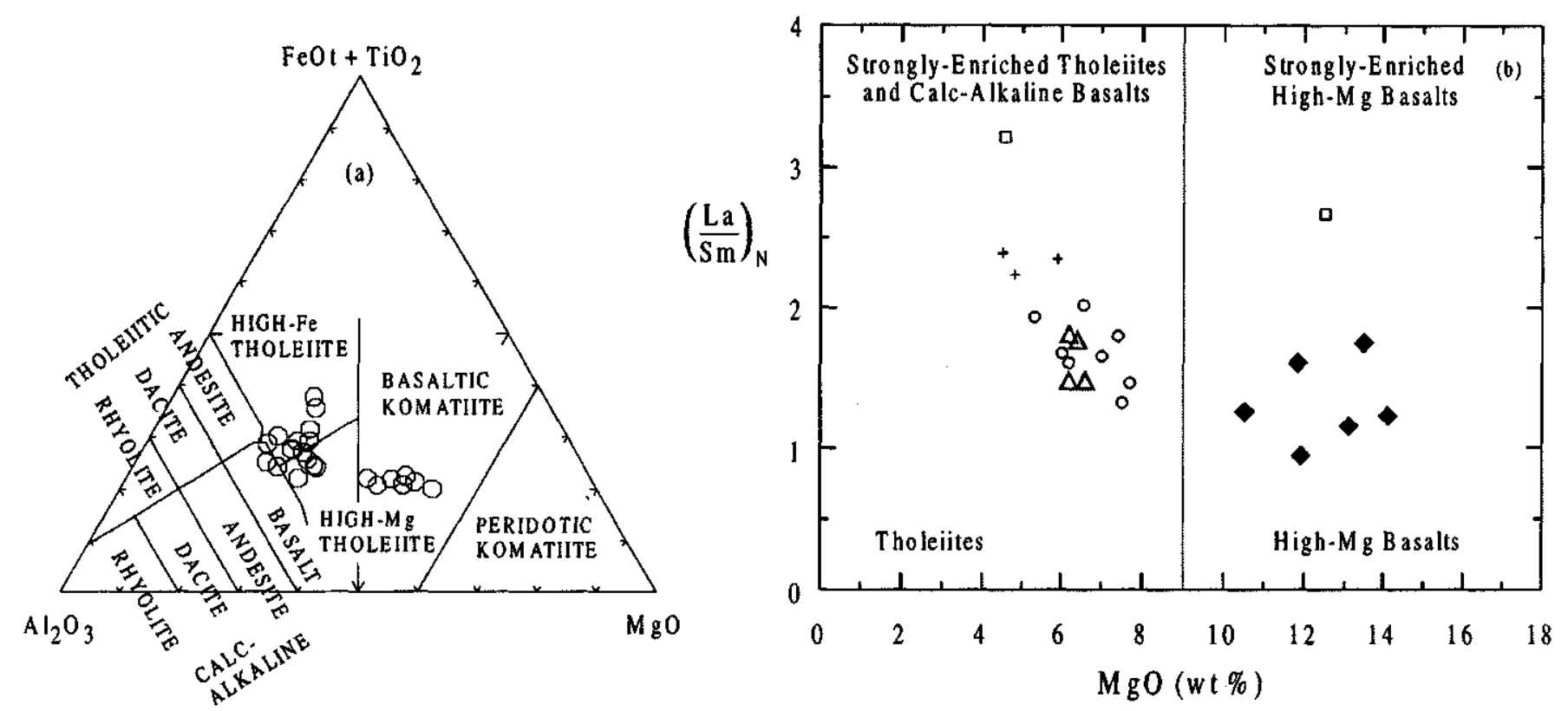

Figure 9 - (a) Diagram after Jensen (1976). BK: Komatiite Basalt; HFT: High Fe Tholeiite; HMT: High Mg Tholeiite. (b) Diagram after Sylvester et al. (1997) with the concentration of $\mathrm{MgO} v \mathrm{~s}$. La/Sm normalized to the chondritic values ofAnders \& Grevesse (1989).
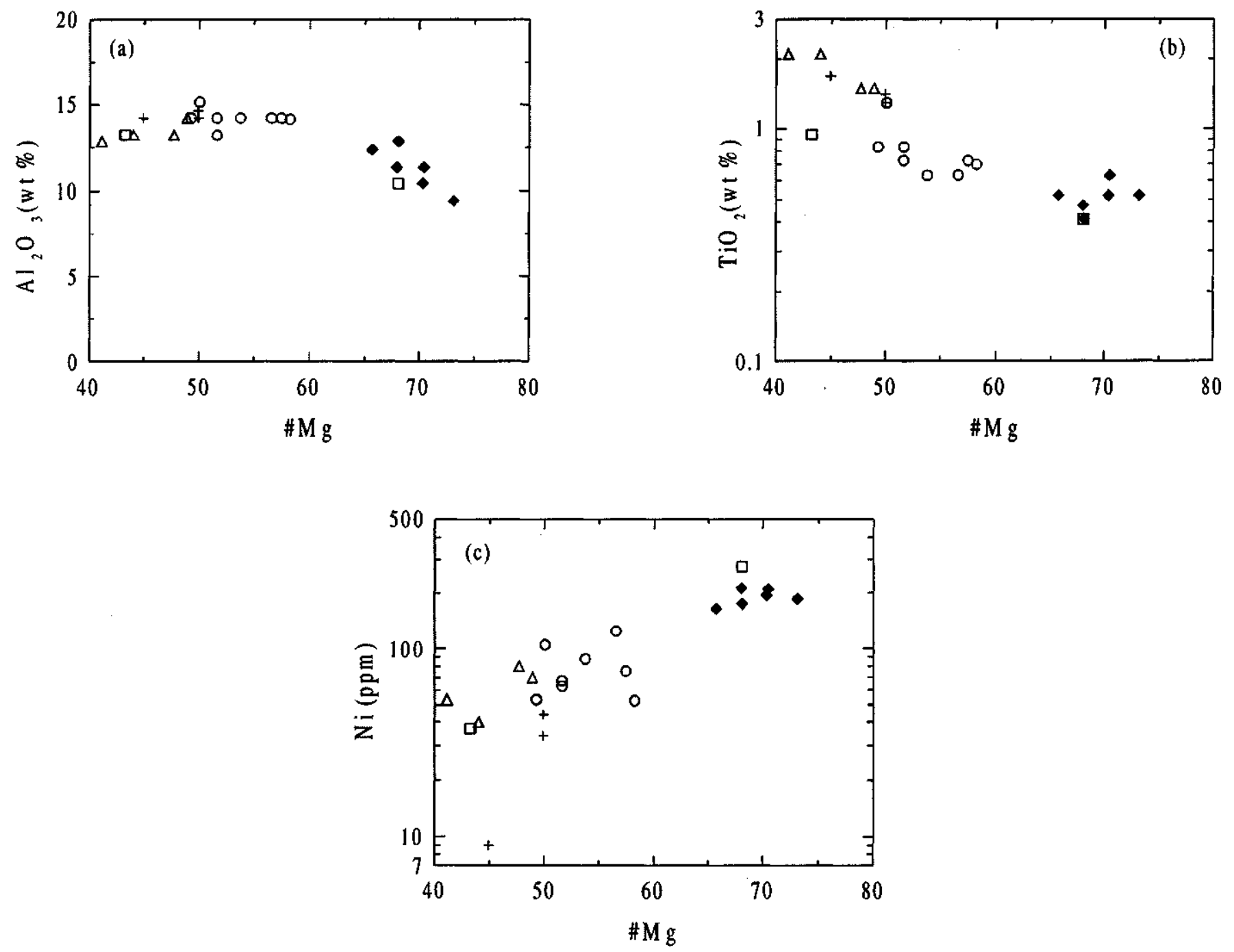

Figure 10 - Binary element-variation diagrams with Mg\# as the differentiation index against (a) $\mathrm{Al}_{2} \mathrm{O}_{3}$; (b) $\mathrm{TiO}_{2}$, (c) Ni. Population symbols as for Figure 8. 


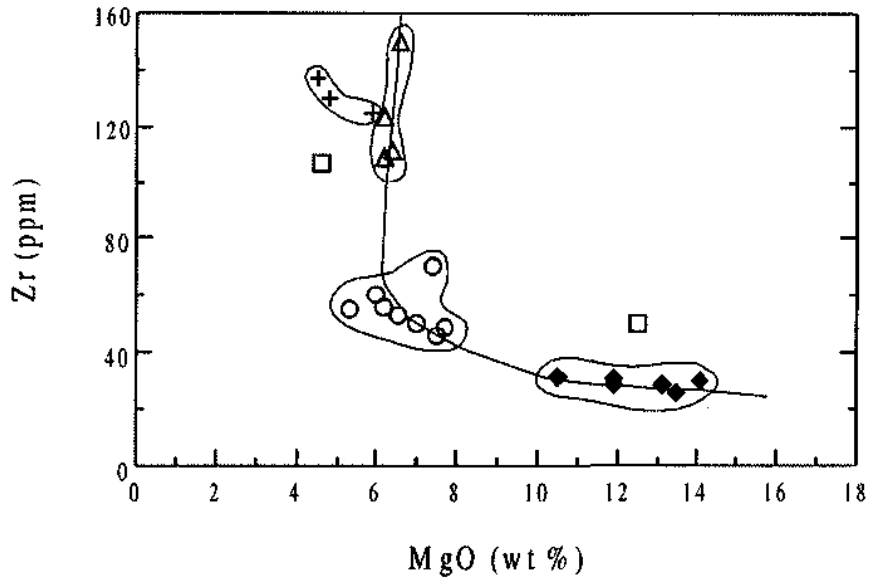

Figure 11 - Binary element-variation diagram of $\mathrm{MgO}$ vs. $\mathrm{Zr}$, separating the groups defined by the populations. The line marks a magmatic-differentiation trend. Population IV marks a mixing line. Population symbols as for Figure 8.

DISCUSSION AND CONCLUSIONS The theory of mantle plumes for the formation of Archean greenstone belts is widely disseminated (Campbell et al 1989, Hill 1993, McDonough \& Ireland 1993, Condie 1994, Park 1997, Arndt et al. 1997). This theory explains both the high temperatures necessary for the formation of komatiites, by way of the plume axis, as well as the lower temperatures for tholeiitic basalt formation, by way of crystallization in the region denominated the plume head. The better part of Archean basalts and mafic plains have a $\mathrm{Th} / \mathrm{Ta}$ and $\mathrm{La} / \mathrm{Yb}$ ratio distribution similar to the submarine plateau basalts derived from depleted mantle sources (Condie 1994). The REE patterns of the studied metabasalts provide evidence for the similarities with P-MORB basalt types and also display an evolution by differentiation of the entire sample population. This is also in accordance with the proposal by Arndt et al. (1997), who indicate that from the partial fusion of an asthenospheric, deepseated mantle plume differentiation by fractional crystallization at shallower levels will follow. Campbell et al. (1989) affirm that the Archean plumes had a mantle source depleted in LREE, which is also observed in the most primitive basalts of the RVGB on a Th/Ta versus $\mathrm{La} / \mathrm{Yb}$ diagram (Fig. 12). On the basis of the distribution of the incompatible elements of greenstone basalts, Condie $(1994,1997)$ affirm that basalts with affinities similar to those of basalts in islandarcs and submarine plateaux dominated during the Archean. The incompatible elements of the primitive basalts of the RVGB lie within the field defined by present-day submarine-plateau basalts (Fig. 12).

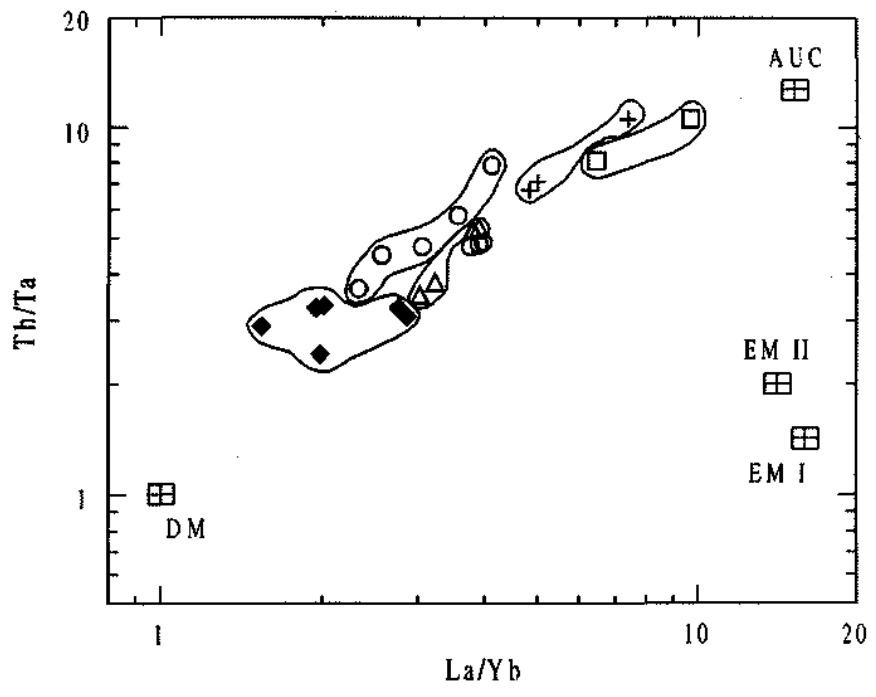

Figure 12 - Element-ratio diagram for Th/Ta vs. La/Yb (after Condie 1994) for the metabasalts of the Nova Lima Group, RVGB. DM: depleted mantle; EM 1 and EM II: enriched mantle; AUCC: Archean upper continental crust. Population symbols as for Figure 8.

On the basis of the trace-element study, at least some of the basalts (Populations I, II and III) are interpreted as submarine-plateau basalts derived from a mantle plume source. The binary element-variation and REE diagrams show that magmatic differentiation and fractional crystallization took place from a Population I-type source. Populations IV and V present evidence of incompatible-element assimilation processes. This enrichment displays a process of mixture that can be explained either by the assimilation resulting from ascendant fluids from a subducting slab, by crustal contamination, or by the mixture of a depleted and enriched mantle source (Condie 1994). The association of basalts with felsic volcanic rocks (dacites) and the absence of direct evidence for continental crust favors a process of assimilation by ascendant fluids from a subducting slab in an island-arc or back-arc environment.

Acknowledgements The first author thanks the CPRMSUREG/BH for the support received and colleagues Frederico O. Raposo, Ludmila M. M. Pereira e Orivaldo F. Baltazar for the valuable cooperation. LM Lobato's research has benefited throughout the years from grants provided by PADCT-FINEP and CNPq, and bursaries by the latter.

\section{References}

Anders E. \& Grevesse N. 1989. Abundances of the elements: Meteoritic and solar. Geochimica et Cosmochimica Acta 53:197-214

Arndt N.T. \& Nisbet E.G. 1982. What is a komatiite? In: N.T. Arndt \& E.G. Nisbet (eds.) Komatiites. London, George Alien \& Unwin, 19-26

Baltazar O.F. \& Silva S.L. da 1996. Projeto Rio das Velhas:Mapa Geologico Integrado do Supergrupo Rio das Velhas, excala 1:100.000, Belo Horizonte, DNPM/CPRM.

Baltazar O.F. \& Pedreira A.J. 1998. Associa96es de litofacies. In: M. Zucchetti \& O.F. Baltazar (org.) Projeto Rio das Velhas: Texto Explicativo do Mapa Geologico InteBaltazar (org.) Projeto Rio das Velhas: Texto Explicativo do Mapa Geologi
grado, escala 1:100.000, 2 ed. Belo Horizonte, DNPM/CPRM, 43-47

Bau M. 1991. Rare-earth element mobility during hydrotermal and metamorphic fluid-rock interaction and the significance of the oxidation state of europium. Chemical interaction and the sign

Campbell I.H., Griffiths R.W., Hill R.I. 1989. Melting in an Archaean mantle plume: heads it's basalts, tails it's komatiites. Nature, 339:697-699

Condie K.C. 1985. Secular variation in the composition of basalts: an index to mantle evolution. Journal of Petrology, 26:545-563

Condie K.C. 1989. Plate Tectonics and Crustal Evolution. 3 ed. Oxford, Pergamon, 475 p. Condie K.C. 1994. Greenstones through time. In: C.K. Condie (ed.) Archean Crustal Evolution. Amsterdam, Elsevier, 85-120

Dorr II J.V. 1969. Physiographic Stratigraphic and Structural Development of the QuadriIdtero Ferrifero, Minus Gerais. U. S. Geological Survey Professional Paper. 614-A HOp.

Humphris S. 1984. The mobility of the rare earth elements in the crust. In: P. Henderson (ed) Rare earth element geochemistry. Amsterdam, Elsevier, 317-342

Ladeira E. A. 1980. Metalogenesis of Gold at the Morro Velho Mine, and in the Nova Lima District, Quadrilátero Ferrifero, Minas Gerais, Brazil. University of Western Ontario, London, Ontario, Canada, Ph D. Thesis, $272 \mathrm{p}$.

McDonough W.F. \& Ireland T.R. 1993. Intraplate origin of komatiites inferred from trace elements in glass inclusions. Nature, 365:432-434

Michard A. 1989. Rare earth element systematics in hydrotermal fluids. Geochimica et Cosmochimica Acta, 53:745-750

Morris P.A. \& Witt W.K. 1997. Geochemistry and tectonic setting of two contrasting Archaean felsic volcanic associations in the Eastern Goldfields, Western Australia. Precambrian Research, 83:83-107
Oliveira G.A.I., Clemente P.L.C., Vial D.S. 1983. Excursão a Mina de Ouro de Morro Vetho. In: SBG, Simposio de Geologia de Minas Gerais, 2, Belo Horizonte, Anais, Belo Horizonte, 3:497-505

Park R.G. 1997. Early Precambrian plate tectonics. South African Journal of Geology, $100 \cdot 23-35$

Pedreira AJ \& Silva S.L. 1996. Sistemas deposicionais do Greenstone Belt Rio das Velhas, Quadrilatero Ferrifero, Minas Gerais. In: SBG, Congresso Brasileiro de Geologia, 39 Salvador, Anais 1:138-140

Sun S.S. \& McDonough W.F. 1989. Chemical and isotopic systematics of oceanic basalts: implications for mantle composition and processes. In: A.D. Saunders \& M.J. Norry (eds.) Magmatism in ocean basins. Geol. Soc. London. Spec. Pub. 42:313-345

Sylvester P.L., Harper G.D., Byerly G.R., Thurston P.C. 1997. Volcanic aspects. In: M.J. De Wit \& L. D. Ashwal (eds.) Greenstone Belts. Oxford, Clarendon Press, 55-90

Vieira F.W.R. 1991. Petrplogia e litogeoquirnica do setor W do Greenstone Belt Rio das Velhas, MG. In: Simp. Int. Min., 1, e Simp. Int. Geol., 1, Nova Lima, Grupo AMSA, 130-154

Vieira F.W.R. \& Oliveira G.A.I. 1988. Geologia do Distrito Aurifero de Nova Lima, Minas Gerais. In: C. Schobbenhaus \& C.E.S. Coelho (coord.) Principals Depositos Minerals do Brasil. Brasilia, DNPM/CVRD, 3:377-391

Zucchetti M. 1998. Geoquimica dos Metabasaltos do Grupo Nova Lima, Greenstone Belt Rio das Velhas, Quadrildtero Ferrifero, Minas Gerais. Universidade Federal de Minas Gerais, Belo Horizonte, M. Sc. Dissertation, $97 \mathrm{p}$.

Zucchetti M. Baltazar O.F. Raposo P.O. 1998a. Estratigrafia. In: M. Zucchetti \& O. F Baltazar (coord.) Projeto Rio das Velhas: Texto Explicativo do Mapa Geologico Integrado, escala 1:100.000, 2 ed. Belo Horizonte, DNPM/CPRM, 13-42

Zucchetti M., Lobato L.M., Baars F.J. 1998b. Geoquimica dos Metabasaltos do Grupo Nova Lima, Greenstone Belt Rio das Velhas, Quadrilatero Ferrifero, Minas Gerais. In: SBG, Congresso Brasileiro de Geologia, 40, Belo Horizonte, Anais, 60 